\title{
Nutrient Addition and Moisture Promote the Invasiveness of Crimson Fountaingrass (Pennisetum setaceum)
}

\author{
Sebataolo J. Rahlao, Karen J. Esler, Sue J. Milton, and Phoebe Barnard*
}

\begin{abstract}
We conducted a greenhouse study to examine the effects of different habitat conditions and environmental resources on the growth rates of crimson fountaingrass, an invasive, alien, perennial grass in South Africa. To help understand the factors promoting the spread of this emergent alien grass, we investigated the effects of temperature regimes, nutrient and moisture addition, and soil type on seedling growth rates and biomass allocation. Our results suggest that crimson fountaingrass seedlings do not tolerate drought because they died within 1 mo without water. Additional nutrients and extra water increased seedling growth rates throughout the study period. Higher temperatures with extra moisture increased seedling growth rates and the development of belowground biomass throughout the study period. This study demonstrates the importance of available environmental resources and their interaction with some habitat conditions in promoting crimson fountaingrass growth. We suggest that soil moisture and nutrient availability are critical factors affecting successful establishment of crimson fountaingrass in arid environments. Managers should target seedlings for removal following precipitation and in areas of nutrient enrichment, such as near rivers and at road-river crossings.
\end{abstract}

Nomenclature: Crimson fountaingrass, Pennisetum setaceum (Forsk.) Chiov. PESSA.

Key words: Alien invasive grass, greenhouse experiment, growth conditions, seedling biomass accumulation.

Success in managing invasive, alien plants partly depends on the knowledge of factors limiting their recruitment (AlvarezAquino et al. 2004). The performance of alien species in new habitats depends on the habitat conditions and on the available environmental resources, where resource-poor environments often support natives better than aliens (Daehler 2003). The availability of resources in a new habitat and reduced competition from resident species renders plant communities vulnerable to invasion. Fluctuations in resource availability may occur because of their reduced uptake by resident vegetation or because of an increased supply and facilitation relative to their uptake (Davis et al. 2000). For example, in dry regions, augmentation of water supply increases the invasibility of vegetation, either as a direct effect of water supply or through improved access to mineral nutrients (Davis et al. 2000; Dukes and Mooney 1999). Soil moisture is the primary ecological driver in many environments, especially in deserts, because of the low frequency and high variability of precipitation and because of the high potential evapotranspiration (Noy-Meir 1973; Reynolds et al. 2004).

Prevention of invasion into natural habitats is constrained by a lack of knowledge about requirements of invasive species for recruitment, growth, and survival. The perennial crimson fountaingrass is an invasive, $\mathrm{C}_{4}$ bunchgrass, native to the North African arid Mediterranean area of the Atlas Mountains and Middle East (Williams et al. 1995). It invades many natural habitat types (Joubert and Cunningham 2002; Milton et al. 1998; Tunison 1992), which include broad altitudinal ranges (Tunison 1992; Williams et al. 1995), varying rainfall and water conditions (Joubert and Cunningham 2002; Williams and Black 1994), and varying soil types (Milton et

\footnotetext{
DOI: 10.1614/WS-09-091.1

*First, second, and third authors: Centre for Invasion Biology, Department of Conservation Ecology and Entomology, Stellenbosch University, Private Bag X1, Matieland 7602, South Africa; fourth author: Climate Change and BioAdaptation Division, Kirstenbosch Research Centre, South African National Biodiversity Institute, Private Bag X7, Claremont 7735, South Africa; third and fourth authors: DST Centre of Excellence, Percy FitzPatrick Institute of African Ornithology, University of Cape Town, Rondebosch 7701, South Africa. Current address of first author: Energy, Environment and Climate Change Programme, Energy Research Centre, University of Cape Town, Private Bag X3, Rondebosch 7701, South Africa. Corresponding author’s E-mail: sebataolo.rahlao@uct.ac.za
}

al. 1998). In South Africa, crimson fountaingrass has been declared a category 1 weed and invader under the Conservation of Agricultural Resources Act of 1983 (amended in 2001), which must be prevented and controlled. This declaration is a result of crimson fountaingrass's promotion of fire in parts of the world, such as Hawaii (Williams et al. 1995) and South Africa (Rahlao et al. 2009). Understanding and identifying environmental resources that promote the success of invasive, alien species during the critical life stages can be used to focus their management (Ward et al. 2006).

The objective of this study was to experimentally assess seedling survival and the growth of crimson fountaingrass under differing environmental resources. The hypothesis that seedlings will perform better in nutrient-rich soils and with high soil moisture availability was tested under two temperature alternatives. The experiment was performed by establishing seedlings in two greenhouse environments and monitoring their survival and growth throughout a period of 8 mo. Based on other studies with this species, as well as generalizations about known invaders, we predicted that (1) crimson fountaingrass seedlings would perform better with high, than with low, water and nutrient availability, (2) nutrient-rich soils would promote the growth of crimson fountaingrass more than nutrient-poor soils, and (3) crimson fountaingrass seedlings would perform better in moderate, than in high, temperatures.

\section{Materials and Methods}

Experimental Design. Crimson fountaingrass seeds were collected from Prince Albert $\left(33^{\circ} 10^{\prime} \mathrm{S}, 22^{\circ} 17^{\prime} \mathrm{E}\right)$, Western Cape Province, South Africa, during December 2006. Crimson fountaingrass occurs along roadsides in this arid area and has the possibility of invading seminatural areas away from roadsides (see Rahlao et al. 2009 for more details). The seeds were later germinated in soil trays in a greenhouse (natural lighting, 31/18 C mean maximum/minimum temperatures) until they germinated by the end of April 2007. The germinated seedlings were transplanted into 1.2-L plastic bags and maintained at ambient temperatures without watering for 2 wk. In June 2007, a total of 120 seedlings were 
Table 1. Properties of the two soil types used for growing crimson fountaingrass seedlings in the two temperature regimes (greenhouses).

\begin{tabular}{|c|c|c|}
\hline Soil properties & Stellenbosch & Kirstenbosch \\
\hline Soil pH & 5.9 & 6.3 \\
\hline $\mathrm{N}$ total $(\%)$ & 0.038 & 0.152 \\
\hline$P(p p m)$ & 2 & 178 \\
\hline $\mathrm{K}\left(\mathrm{cmol} \mathrm{kg}^{-1}\right)$ & 0.08 & 0.49 \\
\hline $\mathrm{Ca}\left(\mathrm{cmo} \mathrm{kg}^{-1}\right)$ & 0.33 & 6.51 \\
\hline $\mathrm{Mg}\left(\mathrm{cmol} \mathrm{kg}^{-1}\right)$ & 0.37 & 1.27 \\
\hline $\mathrm{CEC}\left(\mathrm{cmol} \mathrm{kg}^{-1}\right)$ & 1.55 & 5.34 \\
\hline Clay $(\%)$ & 2.0 & 1.4 \\
\hline Silt (\%) & 3.6 & 6.0 \\
\hline Sand $(\%)$ & 94.4 & 92.6 \\
\hline Mechanical classification & Sand & Sand \\
\hline
\end{tabular}

translocated into 3.9-L pots containing two different types of soil (Table 1). Two separate greenhouse treatments were conducted to determine the effect of temperature, water, nutrients, and soil type on crimson fountaingrass seedling growth and reproductive rates. Seedlings were randomly assigned to four different treatments in a factorial design, with two alternatives of greenhouse conditions $(n=2 \times 60)$ to assess temperature effects, two alternatives of fertilizer addition $(n=2 \times 60)$, three alternatives of moisture content $(n=3 \times 40)$, and two soil-type alternatives $(n=2 \times 60)$, including five replicates (Table 2). The experiment was conducted under two temperature ranges in greenhouses located at the South African National Biodiversity Institute (SANBI) in Cape Town, South Africa, from June 2007 to January 2008. The typical temperatures in the greenhouses ranged between 30 and $45 \mathrm{C}$ (mean $=33 \mathrm{C}$ ) for the hot, and between 15 and $30 \mathrm{C}$ (mean $=21.6 \mathrm{C}$ ) for moderate, greenhouse temperatures, respectively.

To estimate soil-moisture effects on growth, the watering treatments were divided into high-water plants that received $150 \mathrm{ml}$ three times a week, low-water plants that received $150 \mathrm{ml}$ once a week, and no-water plants that did not receive water. These treatments simulate rainfall patterns within the full range of the regions $\left(1,045\right.$ and $348 \mathrm{~mm} \mathrm{yr}^{-1}$ for high and low precipitation, respectively) that are at high risk of invasion by crimson fountaingrass (Rahlao 2009). The dry treatment simulates a prolonged drought following seedling establishment. These three soil moisture treatments were achieved by the use of overhead automatic sprinklers ${ }^{1}$ in each greenhouse. The system has been used in similar studies (Daehler and Goergen 2005; Goergen and Daehler 2001; Poulin et al. 2007) and has been effective in ensuring slow water absorption and less runoff.

Seedlings assigned to nutrient/fertilization treatments received slow-release fertilizer ${ }^{2}(7-1-3 \mathrm{~N}-\mathrm{P}-\mathrm{K})$ added in aqueous form (Table 2). The soil effects were tested with two different soil types, one rich in phosphorus, potassium, nitrogen, and calcium as determined by a professional laboratory analysis ${ }^{3}$, and the other untreated sand, poor in all nutrients. Both soils had a high sand component (Table 1). The nutrient rich soil was similar to soils at sites where crimson fountaingrass occurs in the field (near roadsides and on road-river crossings).

At the end of the experiment, inflorescences of the grass were removed and burned to reduce the possibility of invasion from the greenhouses. The roots and leaves were then harvested and oven-dried to a constant mass for $48 \mathrm{~h}$ at $60 \mathrm{C}$ and weighed to estimate the root and shoot biomass.

Data Collection and Statistical Analyses. Seedling height, stem basal diameter, and the number of leaves were monitored every month for 8 mo (June 2007 to January 2008), the time it took for the leaves to begin dying off after producing inflorescences. Seedling survivorship was estimated as the proportion of seedlings surviving at each time interval.

Repeated-measures ANOVA was performed to analyze the effects of the environmental resource conditions (moisture, fertilization, soil type, and temperature regimes) on growth rates and on root and shoot biomass. Survival of transplanted seedlings was measured as the mean count of surviving seedlings for each treatment. Survival analyses were done to compare groups in a generalized nonlinear model to compare the cumulative proportion of seedlings that survived per treatment throughout the study period. All data were tested for normality and variance before further analyses. Statistical analyses were performed using Statistica. ${ }^{4}$

\section{Results and Discussion}

Seedling Growth Rates. Seedlings that received no water died within 1 mo in both greenhouses and were excluded from further analysis. Seedlings with added nutrients had larger basal diameters than those without nutrients throughout the study period $\left(F_{45.6,45.63}=25.8, \mathrm{df}=1, \mathrm{P}<0.0001\right)$. Soil type did not influence seedling growth rates throughout the study period $\left(F_{1.7,1.68}=0.9\right.$, df $\left.=1, \mathrm{P}=0.335\right)$. Seedlings grown in conditions of high soil moisture were consistently larger than those grown in low-moisture conditions under moderate temperature (Figure 1A).

\section{Environmental Resources and Habitat Condition Interac-} tions. The interaction of temperature and soil moisture affected the seedling growth rates throughout the study period (Table 3). Under moderate temperatures, seedlings growing in high-water conditions were consistently larger $\left(F_{35.04,5.01}\right.$ $=11.08, \mathrm{df}=7, \mathrm{P}<0.0001)$ than those in low-water conditions (Figure 1A). However, under hotter conditions,

Table 2. Factorial experimental design, where 120 potted (3.9-L pots) crimson fountaingrass seedlings were randomly assigned to treatments in two different greenhouses to determine the effect of temperature, water, nutrients, and soil type. Seedlings were assigned to four different treatments with two alternatives of greenhouse conditions $(n=2 \times 60)$, two alternatives of fertilizer addition $(n=2 \times 60)$, three alternatives of moisture content $(n=3 \times 40)$, and two alternatives of soil type $(n=2$ $\times 60)$. All treatments were replicated five times. See text for more details.

\begin{tabular}{llll}
\hline Soil moisture $(\mathrm{M})$ & \multicolumn{1}{c}{ Soil type $(\mathrm{S})^{\mathrm{a}}$} & \multicolumn{1}{c}{ Nutrient $(\mathrm{N})$} & \multicolumn{1}{c}{ Temperature $(\mathrm{T})$} \\
\hline $450 \mathrm{ml}([150 \mathrm{ml} \times 3] / \mathrm{wk})(n=40)$ & Nutrient poor sand $(n=60)$ & Nutrients $\left(20 \mathrm{~g} \mathrm{~m}^{-2}\right)(n=60)$ & Hot $=30-45,(n=60)$ \\
$150 \mathrm{ml} /$ week $(n=40)$ & Nutrient rich sand $(n=60)$ & No nutrient $(n=60)$ & Moderate $=15-35,(n=60)$ \\
No moisture $(n=40)$ & & &
\end{tabular}

a The soil effects were tested with two different soil types, one rich in phosphorus, potassium, nitrogen, and calcium, and the other untreated sand, poor in all nutrients. 

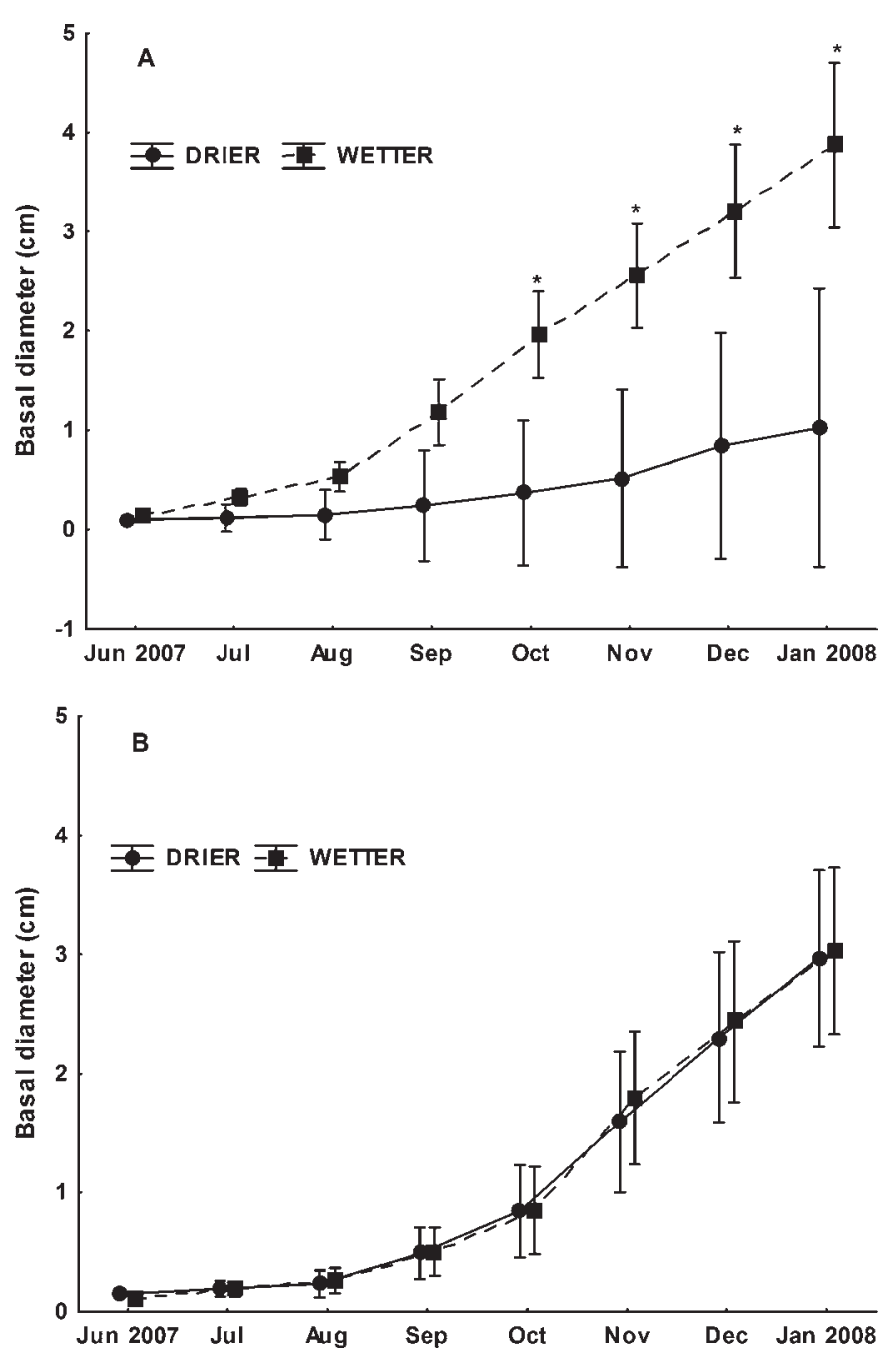

Figure 1. Performance (basal diameter) of crimson fountaingrass seedlings under drier and wetter conditions in two temperature treatments of $(\mathrm{A})$ moderate (15 to $35 \mathrm{C}$ ) and (B) hotter (30 to $45 \mathrm{C}$ ) temperatures. An asterisk $\left(^{*}\right)$ denotes significant differences. Bars indicate standard deviations from the mean.

the amount of water did not have an effect on seedling growth rates throughout the study period $\left(F_{0.38,0.05}=0.11, \mathrm{df}=7\right.$, $\mathrm{P}=0.997$; Figure 1B).

Biomass Responses. Addition of nutrients significantly increased both aboveground and belowground biomass (Table 4). Under the high-temperature regime, crimson fountaingrass seedlings developed significantly more $\left(F_{1,58}\right.$ $=4.2638, \mathrm{P}=0.04341$ ) belowground biomass than under a moderate temperature (Figures $2 \mathrm{~A}$ and $2 \mathrm{~B}$ ). However, there was no difference $\left(F_{1,63}=2.5116, \mathrm{P}=0.11802\right)$ in the
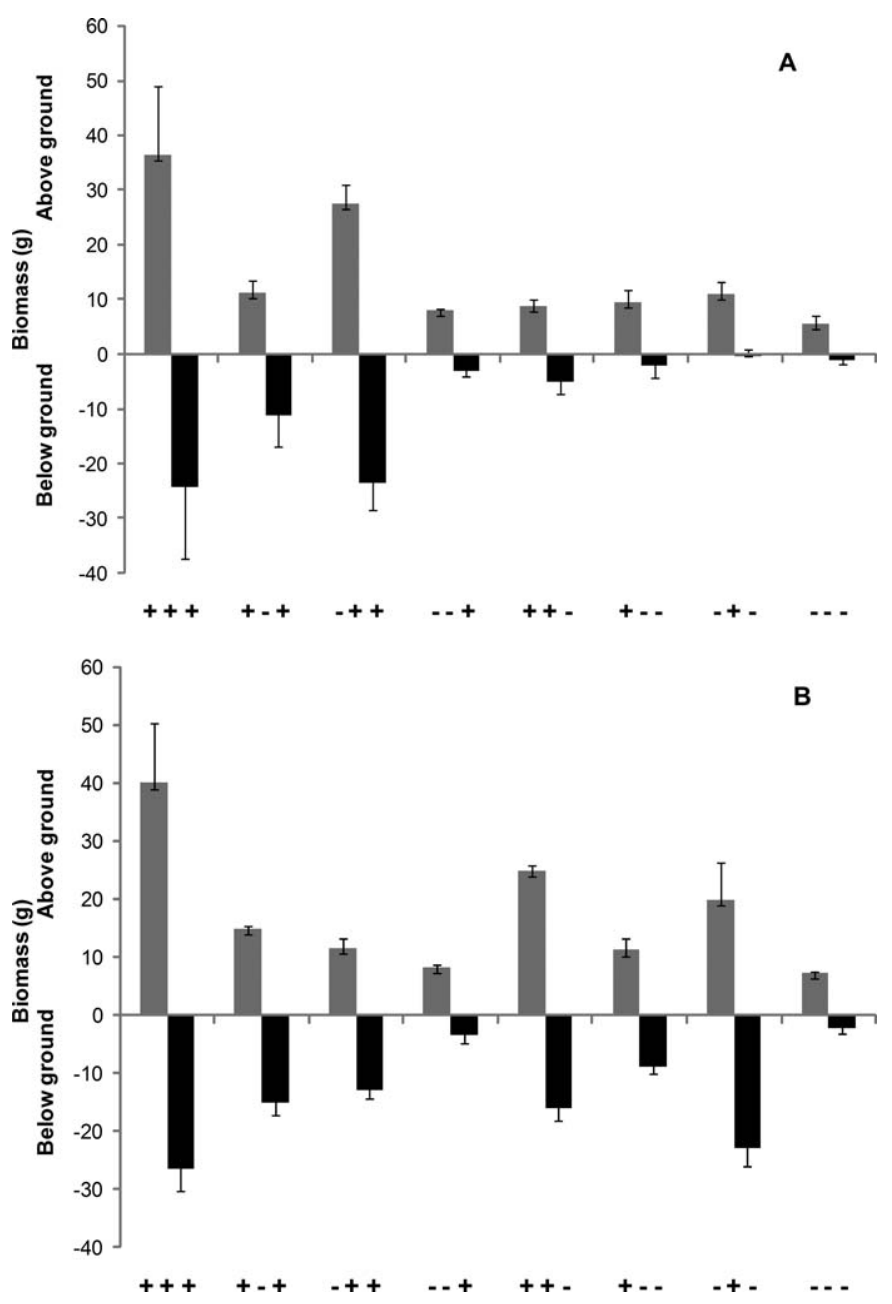

Figure 2. Mean aboveground and belowground biomass allocation in Pennisetum setaceum under (A) moderate temperature and B) hotter temperature regimes A plus symbol (+) implies additional resources to the soil, nutrients, and water, respectively. For example, +++ means rich soil, nutrients added, and high water content. A minus sign (-) implies poor soil, nutrients, and water, respectively. For example, - - - means poor soil, no nutrients added, and low water content. Error bars indicate 1 standard error.

amount of aboveground biomass developed under both temperature regimes. Under low environmental resource conditions, seedlings developed more belowground biomass, especially in hotter temperature regimes (Figure 2B).

Seedling Survival. The proportion of seedlings that survived at the end of the experiment varied significantly among treatments. All seedlings that received no water died within 1 mo in both temperature regimes (Figure 3A). More (90\%) seedlings survived under the high-water treatment than under

Table 3. Mean basal diameter ( \pm SE) of surviving seedlings of crimson fountaingrass after eight months under treatments of temperature/greenhouse and soil type and the addition of water and nutrients.

\begin{tabular}{lccccc}
\hline Greenhouse & Soil type $^{\mathrm{a}}$ & Nutrients + high water & Nutrients + low water & No nutrients + high water & No nutrients + low water \\
\cline { 3 - 6 } & & & & & \\
mot & Rich & $3.60 \pm 0.99$ & $4.38 \pm 0.53$ & $1.60 \pm 0.27$ & $1.50 \pm 0.12$ \\
Hot & Poor & $4.28 \pm 0.30$ & $3.97 \pm 1.04$ & $2.76 \pm 0.21$ & $2.22 \pm 0.20$ \\
Moderate & Rich & $5.18 \pm 0.85$ & $1.50 \pm 0.30$ & $1.76 \pm 0.28$ & $0.53 \pm 0.80$ \\
Moderate & Poor & $5.34 \pm 0.45$ & $1.25 \pm 0.15$ & $3.20 \pm 0.15$ & $0.65 \pm 0.05$
\end{tabular}

${ }^{a}$ The soil effects were tested with two different soil types, one rich in phosphorus, potassium, nitrogen, and calcium, and the other untreated sand, poor in all nutrients. 


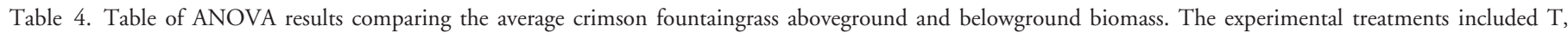

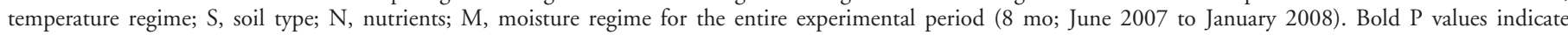
significant effects and interactions.

\begin{tabular}{|c|c|c|c|c|c|}
\hline \multirow[b]{3}{*}{ Source } & \multirow[b]{3}{*}{$\mathrm{df}$} & \multicolumn{4}{|c|}{ Biomass } \\
\hline & & \multicolumn{2}{|c|}{ Belowground } & \multicolumn{2}{|c|}{ Aboveground } \\
\hline & & $F$ & $\mathrm{P}$ & $F$ & $\mathrm{P}$ \\
\hline $\mathrm{T}$ & 1 & 5.216 & 0.026 & 1.173 & 0.283 \\
\hline S & 1 & 5.640 & 0.021 & 9.627 & 0.003 \\
\hline $\mathrm{N}$ & 1 & 25.489 & $<0.0001$ & 31.238 & $<0.0001$ \\
\hline M & 1 & 13.477 & 0.0005 & 10.235 & 0.002 \\
\hline $\mathrm{T} \times \mathrm{S}$ & 1 & 0.378 & 0.541 & 2.651 & 0.108 \\
\hline $\mathrm{T} \times \mathrm{N}$ & 1 & 0.618 & 0.435 & 0.094 & 0.760 \\
\hline$S \times N$ & 1 & 0.826 & 0.367 & 1.438 & 0.235 \\
\hline $\mathrm{T} \times \mathrm{M}$ & 1 & 7.698 & 0.007 & 3.934 & 0.052 \\
\hline$S \times M$ & 1 & 2.979 & 0.089 & 3.889 & 0.053 \\
\hline $\mathrm{N} \times \mathrm{M}$ & 1 & 2.220 & 0.141 & 5.044 & 0.028 \\
\hline $\mathrm{T} \times \mathrm{S} \times \mathrm{N}$ & 1 & 0.243 & 0.624 & 1.574 & 0.214 \\
\hline $\mathrm{T} \times \mathrm{S} \times \mathrm{M}$ & 1 & 1.813 & 0.183 & 0.736 & 0.394 \\
\hline $\mathrm{T} \times \mathrm{N} \times \mathrm{M}$ & 1 & 5.364 & 0.024 & 4.123 & 0.046 \\
\hline $\mathrm{S} \times \mathrm{N} \times \mathrm{M}$ & 1 & 0.083 & 0.774 & 3.072 & 0.084 \\
\hline $\mathrm{T} \times \mathrm{S} \times \mathrm{N} \times \mathrm{M}$ & 1 & 2.529 & 0.117 & 0.208 & 0.650 \\
\hline
\end{tabular}
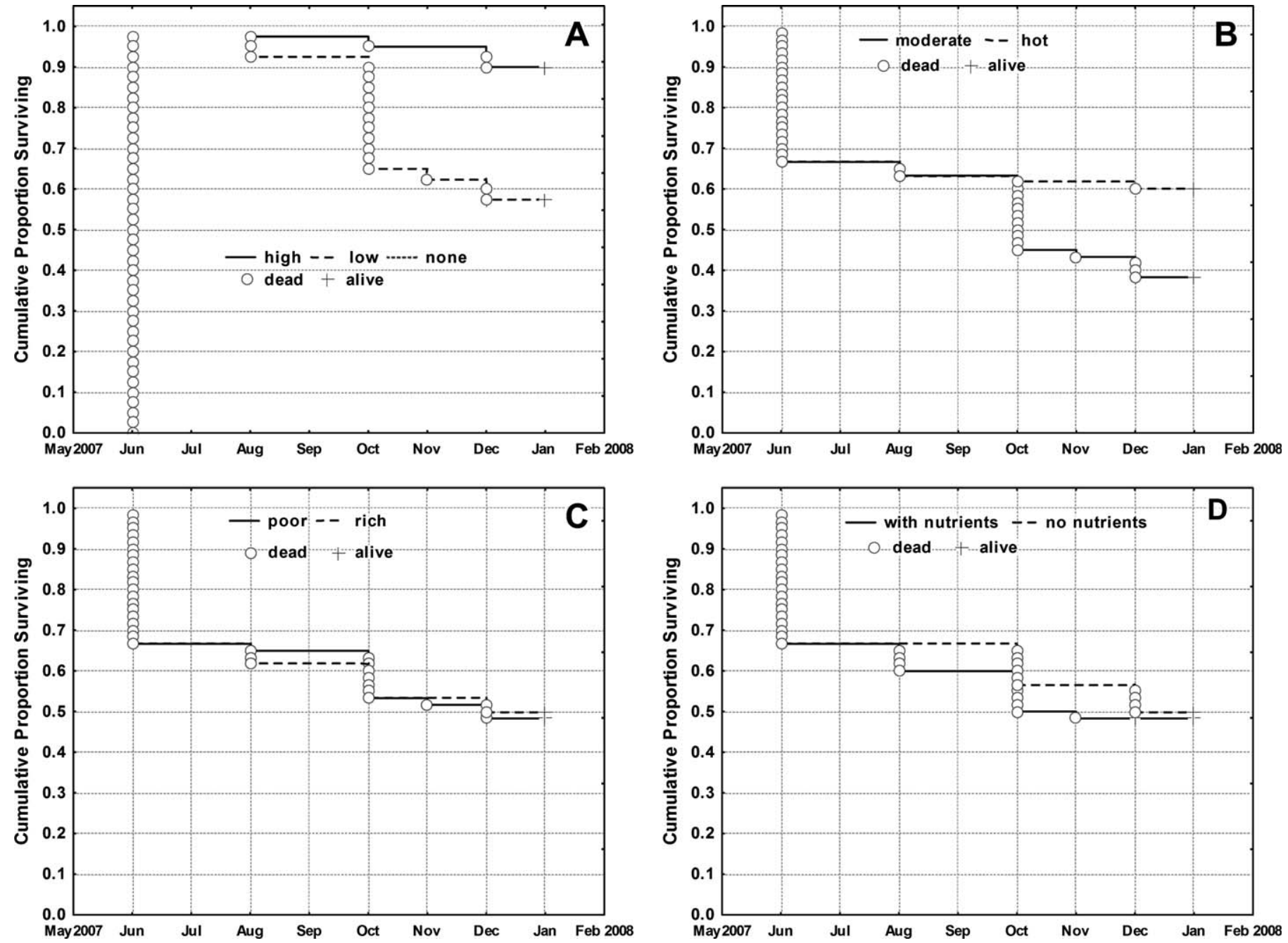

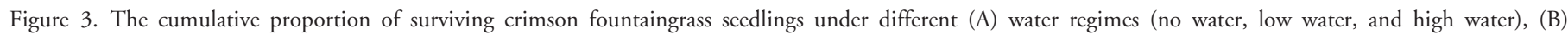

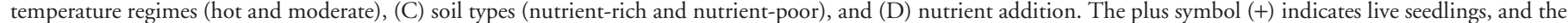
circles $(\bigcirc)$ indicate dead seedlings. 
the low-water treatments (57\%). More seedlings survived under a hot temperature $(60 \%)$ than those under a moderate temperature regime (39\%; Figure 3B). The type of soil and addition of nutrients did not influence the survival rates of crimson fountaingrass seedlings throughout the study period (Figures 3C and 3D). Many seedlings died during the fifth month (October), probably as a result of adjusting to the extreme temperature conditions at that time in the greenhouses.

Phenotypic plasticity and local adaptability allow many alien, invasive species to be highly invasive under variable environmental conditions (Richards et al., 2006). Crimson fountaingrass allocated more resources to root development under hotter temperature regimes (Figure 2B), which could be the plant's strategy to adapt under stressful environments. Williams and Black (1993) reported that under nutrient-rich and high-water conditions, crimson fountaingrass allocated more biomass to leaves in Hawaii. We also found more aboveground biomass in crimson fountaingrass under high environmental resource (nutrients and water) availability. In addition, this study found that under low-resource availability, crimson fountaingrass allocates more resources to root development, probably as a strategy to prevail until favorable conditions return.

In desert ecosystems, limited soil-moisture availability has been recognized as the likely reason for lower rates of infestation by invasive alien species than in more mesic environments (Rejmánek et al. 2004). Crimson fountaingrass seedlings were unable to survive in treatments with no water. Increased soil moisture in these dry areas would likely increase the invasibility of vegetation, either as a direct effect or through improved access to mineral nutrients (Davis et al. 2000; Dukes and Mooney 1999). Invasive alien grasses also respond positively to increased levels of nitrogen and phosphorus in dry, desert regions (Brooks and Pyke 2001; Wilson et al. 1966). Nutrient addition increased both the aboveground and belowground biomass and overall performance in crimson fountaingrass seedlings during the study period.

The amount of water did not affect seedling performance under higher temperatures (Figure 1B). This suggests that once the seedlings have established under these harsh, hotter temperatures, they are able to persist, even if provided only small amounts of water. Areas of crimson fountaingrass occurrence in the field are within the range of those of the hotter greenhouse, which could explain the persistence of crimson fountaingrass in hotter, arid and semiarid areas in South Africa, but our results suggest that this may depend on reasonably regular rainfall at the seedling stage. This result demonstrates the importance of environmental resources (nutrients and water addition) and their interactions with habitat conditions (e.g., air temperature) in promoting crimson fountaingrass growth rates and invasion.

Temperature regime had no effect on plant growth rates or aboveground biomass throughout the study period. This result suggests that crimson fountaingrass can persist and spread in some environments where it is currently absent. This result refutes our initial hypothesis that the plant would perform better under moderate conditions. Crimson fountaingrass seeds are dispersed by wind and water, and seeds produced in habitats with high environmental resources, such as road-river crossings, may be dispersed into habitats with low environmental resource, where they could germinate and persist by allocating resources to root development until favorable habitat conditions prevail.

Our study confirms that environmental resource availability (i.e., water and nutrients) improves growth of an invasive, alien grass species, and that information may, therefore, play an important role in its management and control. Identifying and understanding ideal conditions for successful growth during early stages of this grass are important for its management. Based on our findings, we suggest that managers plan to target seedling removal following precipitation events and in areas subject to nutrient enrichment, particularly at road-river crossings, where crimson fountaingrass performs well (Rahlao 2009). This could be achieved by having teams uproot grass seedlings early after rainfall at identified localities where the grass poses high risks.

\section{Sources of Materials}

${ }^{1}$ Overhead automatic sprinklers, WM Spilhaus Boland (Edms), Bpk, Stikland Ind. Cape Town, Western Cape, South Africa.

${ }^{2}$ Slow-release fertilizer, Agro-Serve (Pty) Ltd, Bryanston, Bauteng, South Africa.

${ }^{3}$ BEMLAB, Pty., Ltd., Somerset West, Western Cape, South Africa.

${ }^{4}$ Statistica software, Version 8, StatSoft, Inc., 2300 East 14th Street, Tulsa, OK 74104

\section{Acknowledgments}

This study was funded by the Department of Science and Technology, National Research Foundation (DST-NRF), Centre of Excellence for Invasion Biology, Stellenbosch University, South Africa. We sincerely thank Deryck Dewitt of the Climate Change and BioAdaptation Division at SANBI for technical advice and installation of the automatic watering in greenhouses.

\section{Literature Cited}

Alvarez-Aquino, C. G. Williams-Linera, and A. C. Newton. 2004. Experimental native tree seedling establishment for the restoration of a Mexican cloud forest. Restor. Ecol. 12:412-418.

Brooks, M. L. and D. A. Pyke. 2001. Invasive plants and fire in the deserts of North America. Pages 1-14 in K.E.M. Galley and T. P. Wilson, eds. Proceedings of the Invasive Species Workshop: the Role of Fire in the Control and Spread of Invasive Species. Fire Conference 2000: The First National Congress on Fire Ecology, Prevention, and Management. Tallahassee, FL: Tall Timbers Research Station Miscellaneous Publication 11.

Daehler, C. C. 2003. Performance comparisons of co-occurring native and alien invasive plants: implications for conservation and restoration. Annu. Rev. Ecol. Syst. 34:183-211.

Daehler, C. C. and E. M. Goergen. 2005. Experimental restoration of an indigenous Hawaiian grassland after invasion by buffel grass (Cenchrus ciliaris). Restor. Ecol. 13:380-389.

Davis, M. A., P. J. Grime, and K. Thompson. 2000. Fluctuating resources in plant communities: a general theory of invasibility. J. Ecol. 88:528-534.

Dukes, J. S. and H. A. Mooney. 1999. Does global change increase the success of biological invaders? Trends Ecol. Evol. 14:135-139.

Goergen, E. and C. C. Daehler. 2002. Factors affecting seedling recruitment in an invasive grass (Pennisetum setaceum) and a native grass (Heteropogon contortus) in the Hawaiian Islands. Plant Ecol. 161:141-156.

Joubert, D. and P. L. Cunningham. 2002. The distribution and invasive potential of fountain grass Pennisetum setaceum in Namibia. Dinteria 27:37-47.

Milton, S. J., J. H. Hoffmann, R.C.K. Bowie, J. D’Amico, M. Griffiths, D. Joubert, D. Loewenthal, N. N. Moinde, C. Seymour, M. V. Toral-Granda, and R. Wiseman. 1998. Invasive fountain grass on the Cape Peninsula. S. Afr. J. Sci. 94:57-59. 
Noy-Meir, I. 1973. Desert ecosystems: environment and producers. Annu. Rev. Ecol. Syst. 4:25-51.

Poulin, J., A. K. Sakai, S. G. Weller, and T. Nguyen. 2007. Phenotypic plasticity, precipitation, and invasiveness in the fire-promoting grass Pennisetum setaceum (Poaceae). Am. J. Bot. 94:533-541.

Rahlao, S. J. 2009. Current and Future Vulnerability of South African Ecosystems to Perennial Grass Invasions under Global Change Scenarios. Ph.D dissertation. Stellenbosch, South Africa: Stellenbosch University.

Rahlao, S. J., S. J. Milton, K. J. Esler, B. W. van Wilgen, and P. Barnard. 2009. Effects of invasion of fire-free arid shrublands by a fire-promoting invasive alien grass Pennisetum setaceum in South Africa. Austral Ecol. 34:920-928.

Rejmánek, M., D. M. Richardson, and P. Pysek. 2004. Plant invasions and invasibility of plant communities. Pages 332-355 in E. van der Maarel, ed. Vegetation Ecology. Oxford, UK: Blackwell

Reynolds, J. F., P. R. Kemp, K. Ogle, and R. J. Fernández. 2004. Modifying the 'pulse-reserve' paradigm for deserts of North America: precipitation pulses, soil water, and plant responses. Oecologia 141:194-210.

Richards, C. L., O. Bossdorf, N. Z. Muth, J. Gurevitch, and M. Pigliucci. 2006. Jack of all trades, master of some? on the role of phenotypic plasticity in plant invasions. Ecol. Lett. 9:981-993.
Tunison, J. T. 1992. Fountain grass control in Hawaii Volcanoes National Park: management considerations and strategies. Pages 376-393 in C. P. Stone, C. W. Smith, and J. T. Tunison, eds. Alien Plant Invasions in Native Ecosystems of Hawaii. Honolulu, HI: University of Hawaii Press.

Ward, J. P., S. E. Smith, and M. P. McClaran. 2006. Water requirements for emergence of buffelgrass (Pennisetum ciliare). Weed Sci. 54:720-725.

Williams, D. G. and R. A. Black. 1993. Phenotypic variation in contrasting temperature environments: growth and photosynthesis in Pennisetum setaceum from different altitudes on Hawaii. Funct. Ecol. 7:623-633.

Williams, D. G. and R. A. Black. 1994. Drought response of a native and introduced Hawaiian grass. Oecologia 97:512-519.

Williams, D. G., R. N. Mack, and R. A. Black. 1995. Ecophysiology of introduced Pennisetum setaceum on Hawaii: the role of phenotypic plasticity. Ecology 76:1569-1580.

Wilson, A. M., G. A. Harris, and D. H. Gates. 1966. Fertilization of mixed cheatgrass-blue bunch wheatgrass stands. J. Range Manag. 19:134-137.

Received June 2, 2009, and approved December 3, 2009. 